\title{
Castellaniella daejeonensis sp. nov., isolated from soil
}

\author{
Myungjin Lee, ${ }^{1}$ Hae-Min Jung, ${ }^{2}$ Sung-Geun Woo, ${ }^{1}$ Soon-Ae Yoo ${ }^{3}$ \\ and Leonid N. Ten ${ }^{3}$
}

\author{
Correspondence \\ Leonid N. Ten \\ Iten@pcu.ac.kr \\ Soon-Ae Yoo \\ say1000@pcu.ac.kr
}

\author{
${ }^{1}$ Research and Development Division, H-Plus Eco Ltd, BVC 301, KRIBB, Eoeun-dong, Yuseong-gu, \\ Daejeon 305-333, Republic of Korea \\ ${ }^{2}$ Department of Biological Sciences, Korea Advanced Institute of Science and Technology, 373-1, \\ Guseong-dong, Yuseong-gu, Daejeon 305-701, Republic of Korea \\ ${ }^{3}$ Department of Biology and Medicinal Science, Pai Chai University, 14 Yeon-Ja 1 Gil, Seo-Gu, \\ Daejeon 302-735, Republic of Korea
}

The genus Castellaniella was described by Kämpfer et al. (2006) to accommodate species characterized by Gramnegative, short rods that are motile, facultatively anaerobic and denitrifying, and contain ubiquinone Q-8 as the major quinone, phosphatidylethanolamine as the major polar lipid, putrescine as the predominant polyamine and $\mathrm{C}_{16: 0}$, $\mathrm{C}_{16: 1} \omega 7 c, \mathrm{C}_{17: 0}$ cyclo and $\mathrm{C}_{18: 1} \omega 7 c$ and/or $\mathrm{C}_{14: 0} 3-\mathrm{OH}$ as major fatty acids. The type species of the genus, Castellaniella defragrans (Kämpfer et al., 2006), was reclassified from

The GenBank/EMBL/DDBJ accession number for the 16S rRNA gene sequence of strain $\mathrm{MJO6}^{\top}$ is GQ241321.

A two-dimensional thin-layer chromatograph of polar lipids of strain $\mathrm{MJO6}^{\top}$ and fatty acid profiles of strain $\mathrm{MJO6}^{\top}$ and its phylogenetically closest relatives are available as supplementary material with the online version of this paper.
Alcaligenes defragrans (Foss et al., 1998) and Castellaniella denitrificans was proposed to accommodate two strains, NKNTAU (Denger et al., 1997) and TJ4 (Baek et al., 2003), previously identified as strains of Alcaligenes defragrans. Two other members of the genus, Castellaniella caeni (Liu et al., 2008) and Castellaniella ginsengisoli (Kim et al., 2009), were subsequently described. The present paper reports on the characterization of a bacterial strain, designated $\mathrm{MJ} 06^{\mathrm{T}}$, which was isolated from a soil sample. On the basis of 16S rRNA gene sequence data, the strain was found to be a member of the genus Castellaniella. Further study of this strain, based on a polyphasic approach that included chemotaxonomic, physiological and DNA-DNA hybridization analyses, confirmed the position of this strain as a representative of a novel species of the genus Castellaniella. 
Strain $\mathrm{MJ06}^{\mathrm{T}}$ was isolated from oil-contaminated soil collected near an oil reservoir in Daejeon, South Korea. The sample was suspended and spread on R2A agar (Difco) plates after being serially diluted with $50 \mathrm{mM}$ phosphate buffer ( $\mathrm{pH}$ 7.0). The plates were incubated at $30{ }^{\circ} \mathrm{C}$ for 2 weeks. Single colonies on the plates were purified by transferring them on to fresh plates and incubating them again under the same conditions. The isolate was routinely cultured on R2A agar at $30{ }^{\circ} \mathrm{C}$ and was maintained as a glycerol suspension $(20 \%, \mathrm{w} / \mathrm{v})$ at $-70{ }^{\circ} \mathrm{C}$. C. denitrificans DSM $11046^{\mathrm{T}}$, C. defragrans DSM $12141^{\mathrm{T}}$, C. caeni KCTC $12197^{\mathrm{T}}$ and C. ginsengisoli KCTC $22398^{\mathrm{T}}$ were used as reference strains for DNA-DNA hybridization and other experiments.

For phylogenetic analysis of strain $\mathrm{MJ} 06^{\mathrm{T}}$, genomic DNA was extracted by using a commercial genomic DNA extraction kit (Solgent), and PCR-mediated amplification of the 16S rRNA gene and sequencing of the purified PCR product were carried out according to Kim et al. (2005). Full sequences of the 16S rRNA gene were compiled by using SeqMan software (DNASTAR). 16S rRNA gene sequences of related taxa were obtained from the GenBank database. Multiple alignments were performed by using the program CLUSTAL X (Thompson et al., 1997). Gaps were edited in the BioEdit program (Hall, 1999). Evolutionary distances were calculated by using the Kimura two-parameter model (Kimura, 1983). Phylogenetic trees were constructed with the neighbour-joining (Saitou \& Nei, 1987) and maximum-parsimony (Fitch, 1971) methods with the MEGA4 program (Tamura et al., 2007), with bootstrap values based on 1000 replications (Felsenstein, 1985).

A nearly complete $16 \mathrm{~S}$ rRNA gene sequence of strain MJ06 $^{\mathrm{T}}$ (1443 bp) was obtained. Preliminary sequence comparisons against $16 \mathrm{~S}$ rRNA gene sequences deposited in the GenBank database indicated that strain $\mathrm{MJ} 6^{\mathrm{T}}$ belonged to the family Alcaligenaceae, class Betaproteobacteria. On the basis of levels of $16 \mathrm{~S}$ rRNA gene sequence similarity, the closest recognized relatives of strain $\mathrm{MJ} 06^{\mathrm{T}}$ were C. denitrificans $\mathrm{NKNTAU}^{\mathrm{T}}(98.6 \%)$, C. defragrans
$54 \operatorname{Pin}^{\mathrm{T}}(98.3 \%)$, C. ginsengisoli DCY $36^{\mathrm{T}}(97.8 \%)$ and $C$. caeni $\mathrm{Ho}-11^{\mathrm{T}}(97.3 \%)$. Levels of $16 \mathrm{~S}$ rRNA gene sequence similarity between strain $\mathrm{MJ} 6^{\mathrm{T}}$ and the type strains of other recognized species within the family Alcaligenaceae were less than $95 \%$. This relationship between strain MJ06 ${ }^{\mathrm{T}}$ and other members of the family Alcaligenaceae was also evident in the neighbour-joining phylogenetic tree (Fig. 1). Strain $\mathrm{MJ06}^{\mathrm{T}}$, C. denitrificans $\mathrm{NKNTAU}^{\mathrm{T}}$, C. defragrans $54 \mathrm{Pin}^{\mathrm{T}}$, C. caeni Ho- $11^{\mathrm{T}}$ and C. ginsengisoli $\mathrm{DCY} 36^{\mathrm{T}}$ formed a coherent cluster with high bootstrap values in both the neighbour-joining and maximum-parsimony trees. These data indicate that strain $\mathrm{MJ} 06^{\mathrm{T}}$ can be clearly separated from other members of the family Alcaligenaceae with the exception of the four strains given above (Wayne et al., 1987; Stackebrandt \& Goebel, 1994). To differentiate strain $\mathrm{MJ} 6^{\mathrm{T}}$ from its phylogenetically closest relatives, DNADNA hybridization experiments were performed.

The Gram reaction for strain $\mathrm{MJ} 06^{\mathrm{T}}$ was performed by using the non-staining method, as described by Buck (1982). Cell morphology was observed under a Nikon light microscope at $\times 1000$ magnification with cells grown for 2 days at $30{ }^{\circ} \mathrm{C}$ on R2A agar. Catalase and oxidase tests were performed as outlined by Cappuccino \& Sherman (2002). Anaerobic growth was determined at $30{ }^{\circ} \mathrm{C}$ as described by Liu et al. (2008). Assimilation of single carbon sources, enzyme activities and other physiological characteristics were determined with the API ID 32GN, API ZYM, API $20 \mathrm{NE}$ and API $50 \mathrm{CH}$ galleries according to the manufacturer's instructions (bioMérieux). Tests for degradation of DNA [DNase agar (Scharlau), with DNase activity detected by flooding plates with $1 \mathrm{M} \mathrm{HCl]}$, casein, chitin, starch (Atlas, 1993), xylan and hydroxyethyl cellulose (Ten et al., 2004) were performed and then evaluated after 7 days. Growth at different temperatures $\left(10,15,20,25,30,37,42\right.$ and $\left.45^{\circ} \mathrm{C}\right)$ was assessed on R2A agar, nutrient agar, Luria-Bertani (LB) agar (Difco), trypticase soy agar (TSA; Difco) and MacConkey agar after 5 days of incubation. Growth at $\mathrm{pH}$ 5.0-11.0 (at intervals of $0.5 \mathrm{pH}$ units) was evaluated in $\mathrm{R} 2 \mathrm{~A}$ broth at $30{ }^{\circ} \mathrm{C}$.

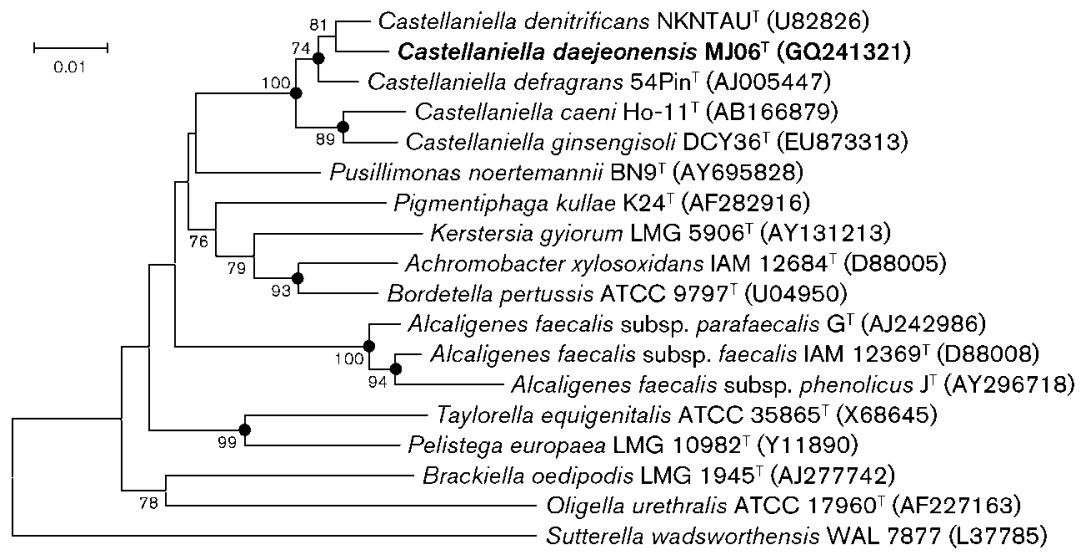

Fig. 1. Neighbour-joining tree, based on $16 \mathrm{~S}$ rRNA gene sequences, showing the phylogenetic position of strain $\mathrm{MJO6}^{\top}$ among neighbouring species selected from the Betaproteobacteria. Bootstrap values (expressed as percentages of 1000 replications) of $>70 \%$ are shown at branch points. Filled circles indicate that the corresponding nodes were also recovered in the tree generated with the maximum-parsimony algorithm. Bar, 1 substitution per 100 nucleotide positions. 
Colonies of strain $\mathrm{MJ}^{\mathrm{T}} \mathrm{6}^{\mathrm{T}}$ grown on R2A agar plates for 2 days at $30{ }^{\circ} \mathrm{C}$ were $0.5-2.0 \mathrm{~mm}$ in diameter, circular, smooth, convex, shiny, transparent and yellowish. On R2A agar, LB agar, TSA and nutrient agar the isolate was able to grow at $25-42{ }^{\circ} \mathrm{C}$, but not at 20 or $45{ }^{\circ} \mathrm{C}$. On MacConkey agar, growth occurred at $30-42{ }^{\circ} \mathrm{C}$, but not at $25^{\circ} \mathrm{C}$. The biochemical characteristics of strain $\mathrm{MJ}^{\mathrm{T}} \mathrm{6}^{\mathrm{T}}$ were similar to those reported for members of the genus Castellaniella (Kämpfer et al., 2006), i.e. positive for assimilation of a number of organic acids (e.g. acetate, caprate and valerate) and amino acids (e.g. L-alanine and L-proline) but negative for $\beta$-galactosidase, utilization of sugars (e.g. sucrose, melibiose and glycogen) and acid production from glucose, sucrose and other carbohydrates. Phenotypic and chemotaxonomic characteristics that differentiate strain $\mathrm{MJ} 06^{\mathrm{T}}$ from its phylogenetically closest relatives are listed in Table 1 .

For the measurement of chromosomal DNA G $+\mathrm{C}$ content, the genomic DNA of strain $\mathrm{MJ06}{ }^{\mathrm{T}}$ was extracted and purified as described by Moore \& Dowhan (1995) and degraded enzymically into nucleosides; the DNA G+C content was determined as described by Mesbah et al. (1989) by using reversed-phase HPLC. Isoprenoid quinones were extracted with chloroform/methanol $(2: 1, \mathrm{v} / \mathrm{v})$, evaporated under vacuum conditions and re-extracted in n-hexane/ water $(1: 1, \mathrm{v} / \mathrm{v})$. The crude quinone in $\mathrm{n}$-hexane was purified by using Sep-Pak Vac silica cartridges (Waters) and was then analysed by HPLC as described by Hiraishi et al. (1996). The cellular fatty acid profile of strain $\mathrm{MJ} 06^{\mathrm{T}}$ was determined from cells grown on TSA for 2 days at $30{ }^{\circ} \mathrm{C}$. The cellular fatty acids were saponified, methylated and extracted according to the protocol of the Sherlock Microbial Identification System (MIDI). The fatty acid methyl esters were then analysed by GC (model 6890; Hewlett Packard) by using the Microbial Identification software package (Sasser, 1990). Duplicate experiments were performed. Polyamines were extracted and analysed according to the methods of Busse \& Auling (1988) and Schenkel et al. (1995). Polar lipids were extracted according to the procedure described by Minnikin et al. (1984) and were identified by two-dimensional TLC followed by spraying with appropriate detection reagents, as described by Lee et al. (2008).

The cellular fatty acid profiles of strain $\mathrm{MJ}^{\mathrm{T}} \mathrm{6}^{\mathrm{T}}$ and the type strains of the four recognized Castellaniella species are given in Supplementary Table S1 available in IJSEM Online. The major components were summed feature 4 $\left(\mathrm{C}_{16: 1} \omega 7 c\right.$ and/or iso- $\left.\mathrm{C}_{15: 0} 2-\mathrm{OH} ; 32.5 \%\right), \mathrm{C}_{16: 0}(22.8 \%)$, summed feature 7 (one of more of $\mathrm{C}_{18: 1} \omega 7 c, \mathrm{C}_{18: 1} \omega 9 t$ and $\mathrm{C}_{18: 1} \omega 12 t, 14.9 \%$ ), summed feature 3 (iso- $\mathrm{C}_{16: 1} \mathrm{I}$ and/or $\left.\mathrm{C}_{14: 0} 3-\mathrm{OH} ; 9.8 \%\right), \mathrm{C}_{12: 0}(9.2 \%)$ and $\mathrm{C}_{17: 0}$ cyclo $(8.0 \%)$, which is a profile typical of members of the genus Castellaniella (Kämpfer et al., 2006; Liu et al., 2008; Kim et al., 2009). However, some minor qualitative and quantitative differences in fatty acid content could be observed between strain $\mathrm{MJ}^{\mathrm{T}}{ }^{\mathrm{T}}$ and its phylogenetically closest relatives. In particular, strain $\mathrm{MJ} 06^{\mathrm{T}}$ differed in having a lower content of $\mathrm{C}_{16: 0}$ and a higher content of
$\mathrm{C}_{12: 0}$. Strain MJ06 ${ }^{\mathrm{T}}$ contained ubiquinone Q-8 as the major respiratory lipoquinone and putrescine as the predominant polyamine. The genomic DNA $\mathrm{G}+\mathrm{C}$ content of strain $\mathrm{MJ06}^{\mathrm{T}}$ was $66.2 \mathrm{~mol} \%$, which lies within the range observed for recognized Castellaniella species (63.5-66.9 mol\%). Two-dimensional TLC of polar lipids extracted from strain $\mathrm{MJ06}^{\mathrm{T}}$ (see Supplementary Fig. S1) showed that the predominant component was phosphatidylethanolamine; it also contained moderate amounts of diphosphatidylglycerol and phosphatidylglycerol, smaller amounts of an unidentified aminolipid, an aminophospholipid and a phospholipid and minor amounts of nine other unidentified polar lipids. This polar lipid profile supported the suggestion that strain $\mathrm{MJ} 6^{\mathrm{T}}$ belongs to the genus Castellaniella, as it was almost identical to the polar lipid composition of the type species of the genus (Kämpfer et al., 2006; Stolz et al., 2005).

DNA-DNA hybridization experiments were performed fluorometrically according to the method of Ezaki et al. (1989), by using photobiotin-labelled DNA probes (Sigma) and microdilution wells (Greiner), with five replications for each sample. The highest and lowest values obtained for each sample were excluded and the means of the remaining three values are quoted as levels of DNA-DNA relatedness. Standard deviations were also calculated based on these three values. Strain MJ06 ${ }^{\mathrm{T}}$ exhibited relatively low levels of DNA-DNA relatedness with respect to $C$. defragrans DSM $12141^{\mathrm{T}}(52 \pm 8 \%)$, C. denitrificans DSM $11046^{\mathrm{T}}(31 \pm 6 \%)$, C. ginsengisoli KCTC $22398^{\mathrm{T}}(18 \pm 7 \%)$ and C. caeni KCTC $12197^{\mathrm{T}}(15 \pm 6 \%)$, indicating that it is not related to them at the species level (Wayne et al., 1987; Stackebrandt \& Goebel, 1994).

The phenotypic and phylogenetic characteristics of strain MJ06 ${ }^{\mathrm{T}}$ indicated that it was a member of the genus Castellaniella. Phylogenetic distinctiveness, together with DNA-DNA hybridization data, confirmed that strain $\mathrm{MJ} 06^{\mathrm{T}}$ represents a species that is distinct from recognized Castellaniella species. There are several phenotypic differences between strain $\mathrm{MJ}^{\mathrm{T}}{ }^{\mathrm{T}}$ and its phylogenetically closest relatives (Table 1). Therefore, on the basis of the data presented, we suggest that strain $\mathrm{MJ}^{\mathrm{T}} \mathrm{6}^{\mathrm{T}}$ represents a novel species of the genus Castellaniella, for which the name Castellaniella daejeonensis sp. nov. is proposed.

\section{Description of Castellaniella daejeonensis sp. nov.}

Castellaniella daejeonensis (dae.jeon.en'sis. N.L. fem. adj. daejeonensis pertaining to Daejeon, a city in South Korea, from where the type strain was isolated).

Cells are facultatively anaerobic, Gram-negative, nonspore-forming, motile rods, $0.3-0.5 \mu \mathrm{m}$ wide and $1.4-$ $1.7 \mu \mathrm{m}$ long. Positive for oxidase and catalase. The optimum temperature for growth is $30{ }^{\circ} \mathrm{C}$. The $\mathrm{pH}$ optimum for growth is 6.5-7.0. Nitrate is reduced to nitrogen gas. Gelatin and casein (weakly) are hydrolysed, but starch, chitin, xylan, hydroxyethyl cellulose and DNA are not. 
Table 1. Differential phenotypic characteristics between strain $M J 06^{\top}$ and its phylogenetically closest relatives in the genus Castellaniella

Strains: 1, MJ06 ${ }^{\mathrm{T}}$; 2, C. denitrificans DSM $11046^{\mathrm{T}}$; 3, C. defragrans DSM 12141 ${ }^{\mathrm{T}}$; 4, C. ginsengisoli KCTC $22398^{\mathrm{T}}$ (data from Kim et al., 2009); 5, C. caeni KCTC $12197^{\mathrm{T}}$. Data are from the present study except where indicated. In API ID 32GN and API 20 NE tests, acetate, lactate, DL-3hydroxybutyrate, valerate, caprate, propionate, malate, L-alanine and L-proline are used as sole carbon sources by all of the strains. The following compounds are not assimilated: melibiose, sucrose, 5-ketogluconate, salicin and glycogen. All of the strains are positive for esterase (C4), esterase lipase (C8), leucine arylamidase and aesculin hydrolysis but negative for $\alpha$-glucosidase, $\beta$-glucosidase (6-bromo-2-naphthyl $\beta$-D-glucopyranoside), $N$-acetyl- $\beta$-glucosaminidase, arginine dihydrolase, $\alpha$-chymotrypsin, $\alpha$-galactosidase, $\beta$-galactosidase, $\beta$-glucuronidase, lipase (C14), trypsin and urease. + , Positive; - , negative; $\mathrm{w}$, weakly positive; ND, no data available.

\begin{tabular}{|c|c|c|c|c|c|}
\hline Characteristic & 1 & 2 & 3 & 4 & 5 \\
\hline Motility & + & $+{ }^{a *}$ & $+{ }^{a}$ & + & $-{ }^{b}$ \\
\hline Growth at $42{ }^{\circ} \mathrm{C}$ & - & $+{ }^{a}$ & $-^{c}$ & + & $-{ }^{b}$ \\
\hline $\mathrm{pH}$ range for growth & $5.0-9.0$ & $5.5-8.5^{a}$ & $6.3-8.4^{c}$ & $5.0-9.0$ & $5.0-8.5^{b}$ \\
\hline Gelatin hydrolysis & + & - & - & - & - \\
\hline \multicolumn{6}{|l|}{ Enzyme activities (API ZYM) } \\
\hline Alkaline phosphatase & - & + & - & + & - \\
\hline Cystine arylamidase & - & - & + & - & - \\
\hline$\alpha$-Fucosidase & - & - & - & $\mathrm{w}$ & $\mathrm{w}$ \\
\hline$\alpha$-Mannosidase & - & - & - & - & + \\
\hline Valine arylamidase & - & $\mathrm{W}$ & + & $\mathrm{W}$ & - \\
\hline Naphthol-AS-BI-phosphohydrolase & - & + & + & + & + \\
\hline L-Fucose & - & - & - & - & + \\
\hline D-Mannitol & + & - & - & + & - \\
\hline D-Sorbitol & + & - & - & - & - \\
\hline 3-Hydroxybenzoate & + & + & + & + & - \\
\hline Inositol & + & - & - & - & - \\
\hline Citrate & - & + & + & + & - \\
\hline$N$-Acetyl-D-glucosamine & - & - & - & + & - \\
\hline Malonate & + & - & - & - & - \\
\hline Itaconate & - & + & - & - & - \\
\hline 2-Ketogluconate & + & - & - & - & - \\
\hline L-Rhamnose & + & - & - & - & - \\
\hline L-Histidine & + & - & - & - & + \\
\hline DNA G $+C$ content $(\mathrm{mol} \%)$ & 66.2 & ND & $66.9^{c}$ & 63.7 & $63.5^{b}$ \\
\hline
\end{tabular}

${ }^{\star}$ Data obtained from: $a$, Kämpfer et al. (2006); b, Liu et al. (2008); c, Foss et al. (1998).

Carbon source utilization and enzyme activities are given in Table 1. Chemotaxonomic characteristics, including fatty acid profile and polar lipid pattern, are described in the text and given in Supplementary Table S1 and Supplementary Fig. S1. In API $50 \mathrm{CHB}$ tests, acid is produced without gas from erythritol, mannose, lactose,
D-arabitol and gluconate but not from other substrates. The DNA G + C content of the type strain is $66.2 \mathrm{~mol} \%$.

The type strain, $\mathrm{MJ06}^{\mathrm{T}}\left(=\mathrm{KCTC} 22454^{\mathrm{T}}=\mathrm{JCM} 16240^{\mathrm{T}}\right)$, was isolated from soil near an oil reservoir in Daejeon, South Korea. 


\section{Acknowledgements}

This work was supported by the Ministry of Environment of the Republic of Korea via the GAIA project (grant 173-081-028).

\section{References}

Atlas, R. M. (1993). Handbook of Microbiological Media. Edited by L. C. Parks. Boca Raton, FL: CRC Press.

Baek, S.-H., Kim, K.-H., Yin, C.-R., Jeon, C. O., Im, W.-T., Kim, K.-K. \& Lee, S.-T. (2003). Isolation and characterization of bacteria capable of degrading phenol and reducing nitrate under low-oxygen conditions. Curr Microbiol 47, 462-466.

Buck, J. D. (1982). Nonstaining $(\mathrm{KOH})$ method for determination of Gram reactions of marine bacteria. Appl Environ Microbiol 44, 992993.

Busse, H.-J. \& Auling, G. (1988). Polyamine pattern as a chemotaxonomic marker within the Proteobacteria. Syst Appl Microbiol 11, 1-8.

Cappuccino, J. G. \& Sherman, N. (2002). Microbiology: a Laboratory Manual, 6th edn. Menlo Park, CA: Benjamin/Cummings.

Denger, K., Laue, H. \& Cook, A. M. (1997). Anaerobic taurine oxidation: a novel reaction by a nitrate-reducing Alcaligenes sp. Microbiology 143, 1919-1924.

Ezaki, T., Hashimoto, Y. \& Yabuuchi, E. (1989). Fluorometric deoxyribonucleic acid-deoxyribonucleic acid hybridization in microdilution wells as an alternative to membrane filter hybridization in which radioisotopes are used to determine genetic relatedness among bacterial strains. Int J Syst Bacteriol 39, 224-229.

Felsenstein, J. (1985). Confidence limits on phylogenies: an approach using the bootstrap. Evolution 39, 783-791.

Fitch, W. M. (1971). Toward defining the course of evolution: minimum change for a specific tree topology. Syst Zool 20, 406-416.

Foss, S., Heyen, U. \& Harder, J. (1998). Alcaligenes defragrans sp. nov., description of four strains isolated on alkenoic monoterpenes $((+)$-menthene, $\alpha$-pinene, 2 -carene, and $\alpha$-phellandrene) and nitrate. Syst Appl Microbiol 21, 237-244.

Hall, T. A. (1999). BioEdit: a user-friendly biological sequence alignment editor and analysis program for Windows 95/98/NT. Nucleic Acids Symp Ser 41, 95-98.

Hiraishi, A., Ueda, Y., Ishihara, J. \& Mori, T. (1996). Comparative lipoquinone analysis of influent sewage and activated sludge by highperformance liquid chromatography and photodiode array detection. J Gen Appl Microbiol 42, 457-469.

Kämpfer, P., Denger, K., Cook, A. M., Lee, S.-T., Jäckel, U., Denner, E. B. M. \& Busse, H.-J. (2006). Castellaniella gen. nov., to accommodate the phylogenetic lineage of Alcaligenes defragrans, and proposal of Castellaniella defragrans gen. nov., comb. nov. and Castellaniella denitrificans sp. nov. Int J Syst Evol Microbiol 56, 815-819.

Kim, M. K., Im, W.-T., Ohta, H., Lee, M. \& Lee, S.-T. (2005). Sphingopyxis granuli sp. nov., a $\beta$-glucosidase-producing bacterium in the family Sphingomonadaceae in $\alpha-4$ subclass of the Proteobacteria. J Microbiol 43, 152-157.

Kim, M. K., Srinivasan, S., Kim, Y.-J. \& Yang, D.-C. (2009). Castellaniella ginsengisoli sp. nov., a $\beta$-glucosidase-producing bacterium. Int J Syst Evol Microbiol 59, 2191-2194.
Kimura, M. (1983). The Neutral Theory of Molecular Evolution. Cambridge: Cambridge University Press.

Lee, M., Lee, H.-W., Im, W.-T., Ten, L. N., Oh, H. W., Liu, Q.-M. \& Lee, S.-T. (2008). Sphingopyxis ginsengisoli sp. nov., isolated from soil of a ginseng field in South Korea. Int J Syst Evol Microbiol 58, 23422347.

Liu, Q.-M., Ten, L. N., Im, W.-T. \& Lee, S.-T. (2008). Castellaniella caeni sp. nov., a denitrifying bacterium isolated from sludge of a leachate treatment plant. Int J Syst Evol Microbiol 58, 2141-2146.

Mesbah, M., Premachandran, U. \& Whitman, W. B. (1989). Precise measurement of the $\mathrm{G}+\mathrm{C}$ content of deoxyribonucleic acid by highperformance liquid chromatography. Int J Syst Bacteriol 39, 159-167.

Minnikin, D. E., O’Donnell, A. G., Goodfellow, M., Alderson, G., Athalye, M., Schaal, A. \& Parlett, J. H. (1984). An integrated procedure for the extraction of bacterial isoprenoid quinones and polar lipids. J Microbiol Methods 2, 233-241.

Moore, D. D. \& Dowhan, D. (1995). Preparation and analysis of DNA. In Current Protocols in Molecular Biology, pp. 2-11. Edited by F. M. Ausubel, R. Brent, R. E. Kingston, D. D. Moore, J. G. Seidman, J. A. Smith \& K. Struhl. New York: Wiley.

Saitou, N. \& Nei, M. (1987). The neighbor-joining method: a new method for reconstructing phylogenetic trees. Mol Biol Evol 4, 406425.

Sasser, M. (1990). Identification of bacteria through fatty acid analysis. In Methods in Phytobacteriology, pp. 199-204. Edited by Z. Klement, K. Rudolph \& D. C. Sands. Budapest: Akademiai Kaido.

Schenkel, E., Berlaimont, V., Dubois, J., Helson-Cambier, M. \& Hanocq, M. (1995). Improved high-performance liquid chromatographic method for the determination of polyamines as their benzoylated derivatives: application to P388 cancer cells. J Chromatogr B Biomed Appl 668, 189-197.

Stackebrandt, E. \& Goebel, B. M. (1994). Taxonomic note: a place for DNA-DNA reassociation and 16S rRNA sequence analysis in the present species definition in bacteriology. Int J Syst Bacteriol 44, 846849.

Stolz, A., Bürger, S., Kuhm, A., Kämpfer, P. \& Busse, H.-J. (2005). Pusillimonas noertemannii gen. nov., sp. nov., a new member of the family Alcaligenaceae that degrades substituted salicylates. Int J Syst Evol Microbiol 55, 1077-1081.

Tamura, K., Dudley, J., Nei, M. \& Kumar, S. (2007). MEGA4: molecular evolutionary genetic analysis (MEGA) software version 4.0. Mol Biol Evol 24, 1596-1599.

Ten, L. N., Im, W.-T., Kim, M.-K., Kang, M.-S. \& Lee, S.-T. (2004). Development of a plate technique for screening of polysaccharidedegrading microorganisms by using a mixture of insoluble chromogenic substrates. J Microbiol Methods 56, 375-382.

Thompson, J. D., Gibson, T. J., Plewniak, F., Jeanmougin, F. \& Higgins, D. G. (1997). The CLUSTAL_X windows interface: flexible strategies for multiple sequence alignment aided by quality analysis tools. Nucleic Acids Res 25, 4876-4882.

Wayne, L. G., Brenner, D. J., Colwell, R. R., Grimont, P. A. D., Kandler, O., Krichevsky, M. I., Moore, L. H., Moore, W. E. C., Murray, R. G. E. \& other authors (1987). International Committee on Systematic Bacteriology. Report of the ad hoc committee on reconciliation of approaches to bacterial systematics. Int J Syst Bacteriol 37, 463464. 